\title{
Bimbingan Konseling Islam untuk Mengatasi Depresi di Hospital Bintulu Malaysia
}

\author{
Ahmad Samerin bin Abu Bakar ${ }^{* 1}$ \\ Hospital Bintulu Malaysia \\ *Email : samerin91@gmail.com
}

\begin{abstract}
This study aims to (1) find out how methods and techniques in Islamic counseling guidance services to deal with early adult depression, (2) to find out how material and media are used in Islamic counseling guidance services to overcome early adult phase depression, (3) to find out the results achieved from Islamic counseling guidance services to overcome depression in the early adult phase at Bintulu Hospital, Sarawak, Malaysia. This research method uses descriptive qualitative method, with data collection techniques such as observation, interviews, and literature study. The results of this study reveal (1) the methods and techniques used in counseling guidance services to overcome depression in Bintulu Hospital patients among the early adult phase is a direct method individually with personal conversation techniques such as dialogue sessions between two parties about the patient's psychological problems (2) Materials in Islamic counseling guidance services provided to patients to deal with depression. (3) Islamic Counseling Guidance Service results in positive changes in patients in Bintulu Hospital.
\end{abstract}

Keywords : Guidance Islamic Counseling; Depression; Early Adult Phase

\begin{abstract}
ABSTRAK
Penelitian ini bertujuan untuk (1) mengetahui bagaimana metode dan teknik dalam layanan bimbingan konseling Islami untuk mengatasi depresi fase dewasa awal, (2) untuk mengetahui bagaimana materi dan media yag digunakan dalam layanan bimbingan konseling Islami untuk mengatasi depresi fase dewasa awal, (3) untuk mengetahui hasil yang dicapai dari layanan bimbingan konseling Islami untuk mengatasi depresi fase dewasa awal di Hospital Bintulu, Sarawak, Malaysia. Metode penelitian ini menggunakan metode deskriptif kualitatif, dengan teknik pengumpulan data berupa observasi, wawancara, dan studi kepustakaan. Hasil penelitian ini mengungkapkan (1) Metode dan teknik yang digunakan dalam layanan bimbingan konseling mengatasi depresi pada pasien Hospital Bintulu dikalangan fase dewasa awal adalah metode langsung secara individual dengan teknik percakapan pribadi seperti sesi dialog antar dua pihak tentang permasalahan psikologi pasien (2) Materi dalam layanan bimbingan konseling Islam yang diberikan kepada pasien untuk mengatasi depresi. (3) Layanan Bimbingan Konseling Islam memberikan hasil perubahan positif pada diri para pasien di Hospital Bintulu.
\end{abstract}

Kata Kunci: Bimbingan Konseling Islami; Depresi; Fase Dewasa Awal 
Ahmad Samerin bin Abu Bakar

\section{PENDAHULUAN}

Depresi merupakan fenomena yang banyak dialami oleh manusia modern. Perkotaan seringkali diidentikkan dengan wilayah supersibuk. Warganya memiliki rutininitas yang berbeda dengan daerah perdesaan. Peneliti menemukan fenomena depresi di kota Bintulu, Sarawak, Malaysia. Menurut observasi yang peneliti lakukan di Hospital Bintulu, terdapat 10 kasus depresi yang terjadi di kalangan individu yang beragama Islam.

Depresi menyerang pada mayoritas individu di lingkungan fase dewasa awal. Hal ini karena usia dewasa awal merupakan usia produktif. Dewasa awal merupakan fase peralihan dari remaja ke dewasa. Pada usia 20-30 tahun, mayoritas individu mendapat tekanan persoalan pendidikan, pekerjaan, pernikahan, dan sebagainya. Hal ini dapat memicu individu mengalami stress. Jika tidak dapat ditangani dengan baik dapat mengarahkan stress kepada depresi.

Depresi memiliki beberapa gejala, seperti insomnia atau kelebihan tidur, hilangnya semangat harapan dan ketertarikan, emosi yang tidak terkawal, merasa sedih, sering merasa murung, dan merasa tidak berharga. Individu yang mengalami depresi akan hilang minat pada kegiatan yang sebenarnya disukai. Ia juga lebih cenderung menarik diri dari lingkungan sosial. Jika dibiarkan terus individu yang mengalami gejala depresi akan memiliki keinginan untuk bunuh diri (Yosep \& Sutini, 2016: 283).

Banyak sekali dampak negatif depresi pada diri individu jika tidak ditangani dengan baik dan lebih awal. Salah satunya adalah kelebihan obesitas, penyakit fisik, penyalahgunaan alkohol dan obat-obatan, konflik keluarga, masalah hubungan dengan orang lain serta masalah di sekolah atau lingkungan kerja, isolasi diri dari sosial, mudah berasa camas, panik atau fobia sosial, cenderung untuk melukai diri sendiri, dan cenderung timbulnya perasaan ingin bunuh diri serta berusaha untuk bunuh diri.

Penelitian tentang depresi pernah dilakukan oleh Ulin Nuhayati (2018) berjudul Pelaksanaan Bimbingan Agama Islam Dalam Mengatasi Depresi Pada Lansia Di Rumah Pelayanan Sosial Lanjut Usia Wening Wardoyo Ungaran. Penelitian tersebut mengungkapkan tentang pelaksanaan bimbingan agama Islam di Rumah Pelayanan Lanjut Usia Wening Wardoyo Ungaran terkait lansia yang mengalami depresi. Hasil penelitian menunjukkan tentang, pelaksanaan bimbingan agama Islam di Rumah Pelayanan Sosial Lanjut Usia Wening Wardoyo Ungaran berjalan dengan baik. Hal ini dilihat dari analisis unsur-unsur bimbingan agama Islam seperti tujuan, materi, metode, pembimbing, dan evaluasi yang sudah sesuai dengan teori fungsi dan tujuan bimbingan dan penyuluhan Islam. Kedua, problematika pelaksanaan bimbingan agama Islam mencakup dua hal yaitu pertama, lansia yang depresi memerlukan perhatian khusus dan bimbingan individu yang lebih mendalam. 
Bimbingan Konseling Islam untuk Mengatasi Depresi di Hospital Bintulu Malaysia

Penelitian tentang bimbingan konseling Islam dalam mengatasi depresi pernah dilakukan juga oleh Novia \& Thohir (2013). Hasil penelitian menunjukkan bahwa bimbingan dan konseling Islam dengan terapi hubungan cukup berhasil dengan persentase $60 \%$, hasil ini dapat dilihat dari perubahan sikap atau perilaku konseli yang awalnya mengunci diri di rumah menjadi berani keluar rumah. Sedangkan Kenwa (2015) melakukan penelitian tentang konseling terhadap depresi postpartum. Menggunakan pendekatan quasi eksperimen, hasilnya menunjukkan bahwa konseling terhadap perempuan pasca melahirkan menunjukkan bahwa konseling berpengaruh terhadap depresi postpartum pada ibu. Penelitian serupa dilakukan oleh Suryani, Widianti, Hernawati, dan Sriati (2016) yang meneliti tentang Psikoedukasi dalam menurunkan tingkat depresi dan kecemasan pada pasien Tuberkolosis Paru. Menggunakan pendekatan eksperimen, hasil penelitian menunjukkan bahwa psikoedukasi efektif dalam mengurangi stres, kecemasan, dan depresi pasien dengan Tuberkulosis Paru.

Penelitian lainnya tentang depresi dilakukan oleh Mutia dan Mulyati (2011) tentang terapi kognitif perilaku bersyukur untuk menurunkan depresi pada remaja. Menggunakan pendekatan eksperimen, hasil penelitian menunjukkan bahwa Gratitude-Cognitive Behavior Therapy (G-CBT) dapat mengurangi tingkat depresi yang dialami remaja. Penelitian lain tentang terapi depresi dilakukan oleh Razak (2013) tentang terapi Spiritual Islami Suatumodel Penanggulangan Gangguan Depresi. Menggunakan pendekatan tazkiyatunnufus, hasilnya menunjukkan bahwa melalui terapi ini mampu mengekspresikan perasaanya kepada kehidupan dan kesehatan mental yang lebih baik. Terapi spiritual Islami bersifat fleksibel, preventif, kreatif dan rehabilitasi. Penelitian lainnya yang sejenis dilakukan oleh Rofiq (2012) tentang terapi Islam dengan strategi thought stopping dalam mengatasi bypochondriasis. Pendekatan yang digunakan adalah pendekatan psikologi Al-Qur'an, hasil penelitian menunjukkan bahwa rekaman pikiran klien tentang pesan stop dari konselor dapat digunakan untuk mengontrol pikiran dan menghilangkan was-was dengan memikirkan pikiran-pikiran yang asertif dengan mengganti pikiran negatifnya melalui kalimat dzikir astafirullahal adzim.

Layanan bimbingan konseling Islam di Hospital Bintulu, amat ditekankan karena pendekatan Islam begitu penting buat menanggulangi permasalahan depresi. Sehingga terdapat novelty dibandingkan dengan penelitian terdahulu yang lebih menekankan terapi atau bimbingan konseling melalui metode lain. Di samping itu, objek penelitian juga berbeda, jika penelitian lain objeknya pada postpartum, penderita tuberkolosis, penelitian ini lebih fokus pada kalangan dewasa awal. Oleh karena itu peneliti tertarik untuk menelaah lebih dalam tentang implementasi layanan bimbingan konseling Islam untuk mengatasi depresi di kalangan fase dewasa awal yang dilaksanakan di Hospital Bintulu, Sarawak, Malaysia.

Tujuan penelitian ini adalah untuk mengetahui: a) metode dan teknik dalam 
Ahmad Samerin bin Abu Bakar

layanan bimbingan dan konseling Islami untuk mengatasi depresi pada fase dewasa awal di Hospital Bintulu, b) materi dan media yang digunakan dalam layanan bimbingan dan konseling Islami untuk mengatasi depresi pada fase dewasa awal di Hospital Bintulu,c) hasil yang dicapai dari layanan bimbingan dan konseling Islami untuk mengatasi depresi pada fase dewasa awal di Hospital Bintulu.

Penelitian ini menggunakan penelitian deskriptif kualitatif. Penelitian deskriptif kualitatif adalah penelitian yang bermaksud untuk mengetahui dan memahami tentang penomena yang dialami objek penelitian misalnya perilaku, persepsi, motivasi, tindakan dan lain-lain secara holistik dan dengan cara deskripsi dalam bentuk kata-kata dan bahasa, pada suatu konteks khususnya yang alamiah dan dengan memanfaatkan berbagai metode ilmiah (Lexy J, Maloeng, 2007:6).

\section{HASIL DAN PEMBAHASAN}

Bimbingan konseling Islam menurut Aunur Rahim Faqih (2001:4) merupakan suatu proses dalam pemberian bantuan terhadap individu agar mampu hidup selaras dengan ketentuan dan petunjuk Allah sehingga dapat mencapai kebahagiaan dalam kehidupan di dunia dan akhirat. Sedangkan landasan utama bimbingan konseling Islam adalah Al-Qur'an dan Sunnah Rasul. Tujuan dari layanan bimbingan konseling Islam menurut Aunur Rahim Faqih (2001:36) adalah untuk membantu individu dari mengalami kembali menghadapi masalah tersebut sekaligus dengan membantu mengembangkan segi-segi positif yang dimiliki dan mungkin dimiliki individu.

Adapun asas-asas bimbingan konseling Islam menurut Aunur Rahim Faqih (2001:22) yaitu: asas-asas kebahagiaan di dunia dan akhirat, asas fitrah manusia itu sendiri, asas "Lillahi ta'ala", asas bimbingan seumur hidup, asas kesatuan jasmaniah-rohaniah, asas keseimbangan rohaniah, asas kemaujudan individu, asas sosialitas manusia, asas kekhalifahan manusia, asas keselarasan dan keadilan, asas pembinaan akhlaqul-karimah, asas kasih sayang, asas saling menghargai dan menghormati, asas musyawarah, dan asas keahlian.

Adapun metode dan tekniknya, Aunur Rahim Faqih (2001:53) membagi kepada metode komunikasi secara langsung dan metode komunikasi secara tidak langsung. Bimbingan konseling Islam menurut Amin (2015:22) adalah suatu upaya membantu individu belajar mengembangkan fitrah dan atau kembali kepada fitrah, dengan cara memberdayakan (empowering) iman, akal, dan kemauan yang dikaruniakan oleh Allah SW'T kepadanya untuk mempelajari tuntunan Allah dan Rasul-Nya, agar fitrah yang ada pada individu itu berkembang dengan benar dan kukuh sesuai dengan tuntunan Allah SWT. Sedangkan tujuan yang ingin dicapai melalui bimbingan konseling Islam menurut Anwar Sutoyo (2015:207) adalah agar fitrah yang dikaruniakan oleh Allah SWT kepada individu bisa berkembang serta berfungsi dengan baik sehingga menjadi pribadi kaaffah dan secara bertahap mampu mengaktualisasikan apa yang diimaninya itu dalam 
Bimbingan Konseling Islam untuk Mengatasi Depresi di Hospital Bintulu Malaysia kehidupan sehari-hari tampil dalam bentuk kepatuhan terhadap hukum-hukum Allah dalam melaksanakan tugas kekhalifan di bumi, serta ketaatan dalam beribadah dengan mematuhi segala perintah-Nya dan menjauhi segala laranganNya. Bimbingan konseling Islam menurut Hamdani Bakran Adz-Dzaky (2006:189) merupakan suatu aktivitas yang memberikan bimbingan, pelajaran, dan pedoman kepada individu (konseli) dalam hal bagaimana seharusnya seorang konseli mengembangkan potensi akal pikirannya, kejiwaannya, keimanan dan keyakinan serta dapat menanggulangi permasalahan hidup dan kehidupannya dengan baik dan benar secara mandiri berdasarkan Al-Qur'an dan As- Sunnah.

Beralih kepada definisi depresi, merupakan suatu kondisi emosional yang biasanya ditandai dengan kesedihan yang mendalam, perasaan tidak berarti dan bersalah, menarik diri dari orang lain, Insomnia, kehilangan selera makan atau sebaliknya, kehilangan hasrat seksual, dan kehilangan minat serta kesenangan dalam aktivitas yang biasa dilakukan Davison (dalam Lubis, 2009:13). Depresi menurut Rathus (dalam Lubis, 2009:13) secara umumnya mengalami gangguan yang meliputi keadaan emosi, motivasi, fungsional, dan gerakan tingkah laku serta kognisi. Depresi menurut Atkinson (dalam Lubis, 2009:13) sebagai suatu gangguan mood yang dicirikan tak ada harapan dan patah hati, ketidakberdayaan yang berlebihan, tak mampu mengambil keputusan memulai suatu kegiatan, tak mampu konsentrasi, tak punya semangat hidup, selalu tegang, dan mencoba bunuh diri.

Depresi menurut Lubis (2009:13) adalah suatu gangguan perasaan (afek) yang ditandai dengan afek disforik (kehilangan kegembiraan/ ghairah) disertai dengan gejala-gejala lain, seperti gangguan tidur dan menurunnya selera makan atau sebaliknya. Depresi biasanya terjadi saat stress yang dialami oleh seseorang tidak kunjung reda, dan depresi yang dialami berkolerasi dengan kejadian dramatis yang baru saja terjadi atau menimpa seseorang. Fase dewasa awal menurut Hurlock (2003:246) adalah individu yang telah menyelesaikan pertumbuhannya dan siap menerima kedudukan dalam masyarakat bersama dengan orang dewasa lainnya. Fase dewasa awal dimulai pada usia 18 tahun sampai 40 tahun, saat perubahan-perubahan fisik dan psikologis yang menyertai berkurangnya kemampuan reproduktif.

Fase dewasa awal menurut Santrock (2002) adalah fase untuk bekerja dan menjalin hubungan dengan lawan jenis, terkadang menyisakan sedikit waktu untuk hal lainnya. Bagi kebanyakan individu, menjadi orang dewasa melibatkan periode transisi yang panjang. Baru-baru ini, transisi dari masa remaja ke dewasa disebut sebagai masa beranjak dewasa yang terjadi dari usia 18 sampai 25 tahun, ditandai oleh ekperimen dan eksplorasi. Banyak individu masih mengeksplorasi jalur karier yang ingin mereka ambil, ingin menjadi individu seperti apa, dan gaya hidup yang seperti apa yang mereka inginkan, hidup melajang, hidup bersama, atau menikah (Arnett dalam Santrock, 2002). 
Faktor penyebab depresi ada tiga yaitu pertama, faktor biologis. Faktorfaktor biologis meliputi (1) Hereditas atau disebut juga faktor keturunan, yaitu resiko terkena depresi karena memiliki orang tua biologis yang menderita gangguan suasana hati seperti depresi, (2) abnormalitas neurobiologis yaitu pola aktivitas gelombang otak yang berbeda saat tidur. Individu yang depresi mengalami lebih sedikit tidur dengan gelombang lambat dan masuk ke tidur lebih cepat pada malam hari dibandingkan dengan individu yang tidak depresi, (3) deregulasi neurotransmitter yaitu berkurangnya neurotransmiter sehingga menyebabkan fungsi otak kurang lancar dan abnormalitas neurotransmiter tersebut dapat mengakibatkan gangguan suasana hati, (4) hormonhormon, individu yang mengalami depresi menunjukkan hiperaktivitas kronis pada sistem kelenjar neuroendokrin dan ketidakmampuan untuk kembali berfungsi normal sesudah pengalaman yang membuat stress dan mengarah pada depresi (Nurhayati, 2018).

Kedua, faktor psikologis. Ada empat teori yang menjelaskan tentang faktor psikologis penyebab depresi yaitu (1) teori psikodinamika, menekankan bahwa depresi berawal dari pengalaman masa kecil individu yang mencegah mereka mengembangkan diri yang kuat dan memiliki perasaan positif, (2) teori behaviorisme, ketika individu tidak dapat mengendalikan stress yang mereka hadapi, mereka kemudian akan merasa tidak berdaya dan berusaha berhenti mencoba mengubah situasi mereka dan hal tersebut akan terus berulang hingga menjadi perasaan depresi, (3) teori kognitif, penedekatan kognitif memberikan sudut pandang bahwa individu-individu yang depresi jarang memiliki pikiran yang positif, mereka memaknai hidup mereka dengan cara memukul diri sendiri dan memiliki harapan negatif tentang masa depan mereka.

\section{Hasil Penelitian}

Hospital Bintulu Sarawak terletak di Jalan Raya Bukit Nyabau Daerah Kota Bintulu di Kepulauan Sarawak Malaysia, dengan jarak kira-kira $12 \mathrm{Km}$ dari ibukota Bintulu, Sarawak. Hospital Bintulu dibangun di atas tanah seluas $1417.8 \mathrm{M}^{2}$ dengan status bersertifikat milik Kementerian Kesihatan Malaysia atau singkatannya KKM. Di hadapan Hospital Bintulu terdapat lampu merah dan jalan raya untuk laluan kenderaan. Sedangkan disamping Hospital Bintulu hanya terdapat kawasan perhutanan liar yang luas. Luas hutan ini meliputi hampir seluruh kawasan hospital bintulu. Hospital Bintulu berjarak $5 \mathrm{Km}$ dengan pemukiman warga sehingga warga yang ingin berkunjung ke Hospital Bintulu harus menggunakan kendaraan umum. Ada pun bagi pasien atau pengunjung yang mampu menggunakan kendaraan pribadi untuk berkunjung ke Hospital Bintulu. Hospital Bintulu Sarawak didirikan pada tahun 1968. Pada mulanya hospital bintulu terletak di Jalan Raya Abang Galau, ibukota Bintulu. Namun, pada 21 Mei 2000, hospital baru telah didirikan terletak di Jalan Raya Bukit Nyabau, dengan 
Bimbingan Konseling Islam untuk Mengatasi Depresi di Hospital Bintulu Malaysia jarak kira-kira $12 \mathrm{KM}$ dari ibukota dan mulai pindah ke lokasi hospital baru tersebut dan beroperasi di situ sehingga kini (Wawancara Bapak Ustadz Khairul Nizam Latif, Pegawai Unit Hal Ihwal Islam Hospital Bintulu, 31 Mei 2019 dan Dokumen Hospital Bintulu, 2019).

Sedangkan Unit Hal Ihwal Islam didirikan dan ditempatkan oleh JAKIM yaitu Jabatan Kemajuan Islam Malaysia disebagian hospital seluruh Malaysia pada tahun 2006. Sedangkan Unit Hal Ihwal Islam di Hospital Bintulu baru beroperasi pada tahun 2013. Pada masa ini, terdapat seramai 62 orang Penolong Pegawai Hal Ehwal Islam (pegawai kader) yang ditempatkan di 56 buah hospital negeri, hospital berpakar dan institusi khas perubatan seperti hospital psikiatri dan Institut Kanser Negara di seluruh Malaysia . Hospital Bintulu memiliki visi yang baik dalam pembangunan kesehatan masyarakat. Selain itu, Unit Hal Ihwal Islam yang memberikan layanan bimbingan konseling Islam juga memiliki visi tersendiri yang singkron dalam mencapai tujuannya. Di bawah ini akan dijelaskan visi, misi serta objektif Hospital Bintulu dan Unit Hal Ihwal Islam.

Adapun visi Hospital Bintulu yaitu: Terwujudnya hospital yang mampu memberikan perkhidmatan penjagaan kesehatan yang cemerlang dan berkualitas. Sedangkan Misinya yaitu: Untuk mencapai atau mewujudkan visi yang diatas, maka visi tersebut ditempuh dengan misi yang bersangkutan yaitu; memastikan akses kepada perkhidmatan kesehatan yang efektif, efisien, dan berkualitas dengan mengamalkan budaya korporat Kementerian Kesehatan Malaysia. Hospital Bintulu memiliki struktur organisasi tersendiri. Struktur ini terdiri dari beberapa maupun divisi, bagian, atau unit. Bermula daripada Pengarah Hospital Bintulu, Kemudian Pengarah Hospital Bintulu dibantu oleh beberapa Timbalan Pengarah. Antara Timbalan Pengarah berikut adalah seperti; Timbalan Pengarah Bagian Klinikal I, Timbalan Pengarah Bagian Klinikal II dan Timbalan Pengarah Bagian Klinikal III. Kemudian terdapat juga Penolong Pengarah Bagian Pengurusan. Setelah itu terdapat juga Bagian Kejuruteraan. Manakala, di bawah Timbalan Pengarah Bagian Klinikal I dibantu oleh dua divisi direktorat; Direktorat Pembedahan dan Direktorat Diagnosis dan Sokongan Klinikal. Kemudian, Direktorat Pembedahan dibantu oleh beberapa unit yaitu; Unit Pembedahan Umum, Unit Ortopedik, Unit Oftalmologi, Unit Kecemasan dan Trauma, Unit Anestesiologi dan Rawatan Rapi dan Unit Otorinolaringologi. Maupun demikian, Direktorat Diagnosis dan Sokongan Klinikal turut dibantu beberapa unit seperti; Unit Pengimejan dan Diagnostik, Unit Kejururawatan, Unit Fisioterapi, Unit Pemulihan Cara Kerja, Unit Sajian dan Dietetik, Unit Klinik Pakar, Unit Optometrik, Unit Keselamatan dan Kesehatan, Unit Kerja Sosial Perobatan, Unit Farmasi, Unit Kawalan Infeksi, Unit Rekod Perobatan, Unit Patologi dan Tranfusi Darah, Unit Forensik, Unit Pendidikan Pasien dan Promosi Kesehatan serta Unit CSSU. 
Semua unit diawasi tugasnya oleh Penyelia Hospital. Selain itu, Timbalan Pengarah Bagian Klinikal II dibantu oleh dua divisi direktorat seperti; Direktorat Wanita dan Kanak-Kanak serta Direktorat Perobatan. Kemudian, untuk memudahkan tugas Direktorat Wanita dan Kanak-Kanak, tugasnya dibantu oleh beberapa unit seperti; Unit Perobatan Umum dan Unit Psikiatri dan Kesehatan Mental. Direktorat Perobatan turut dibantu tugasnya oleh beberapa unit seperti; Unit Obesterik dan Ginekologi serta Unit Pediatrik. Timbalan Pengarah Bagian Klinikal 3 dibantu oleh Direktorat Kualitas. Manakala, untuk memudahkan tugas Direktorat Kualitas, amat dibutuhkan bantuan daripada Unit Kualitas. Maupun begitu, Penolong Pengarah Bagian Pengurusan turut dibantu oleh Direktorat Perkhidmatan Pengurusan, dan untuk memudahkan tugas-tugas bagian atasan ini, dibutuhkan bantuan dari beberapa unit. Unit terbagi sebagai berikut; Unit Pentadbiran Umum, Unit Sumber Manusia, Unit Akaun/Perolehan/Hasil, Unit Pengurusan Aset, Unit Latihan dan Kompetensi, Unit Hal Ihwal Islam, Unit Teknologi Maklumat, Unit Psikologi dan Konseling serta Unit Keselamatan. Manakala, untuk memudahkan tugas-tugas Bagian Kejuruteraan, tugasnya dibantu oleh Unit Sokongan. Adapun penjelasan lebih lanjut akan dipaparkan di dalam bagian lampiran.

\section{Metode dan Teknik Layanan Bimbingan Konseling Islam}

Metode dan teknik bimbingan konseling Islam menurut Aunur Rahim Faqih yaitu metode sering kali diartikan sebagai cara untuk mendekati masalah sehingga diperoleh hasil yang memuaskan, sementara teknik merupakan penerapan metode dalam praktek. Metode dan teknik menurut Aunur Rahim Faqih (2001:54) yaitu: a) metode langsung, metode langsung metode langsung (metode komunikasi langsung) adalah metode di mana pembimbing melakukan komunikasi langsung yakni bertatap muka dengan orang yang dibimbingnya. b) metode tidak langsung, metode tidak langsung adalah dalam bimbingan konseling Islam melalui media lain seperti tv, surat kabar dan lainya. Metode langsung adalah metode ketika pembimbing melakukan komunikasi langsung yakni bertatap muka dengan orang yang dibimbingnya.

Metode ini dirinci sebagai berikut: a Metode individual. Pembimbing dalam hal ini melakukan komunikasi langsung secara individual dengan pihak yang dibimbingnya. Hal ini dapat dilakukan dengan mempergunakan teknik: wawancara atau percakapan pribadi; yakni pembimbing melakukan dialog langsung tatap muka dengan pihak yang dibimbing. Kunjungan ke rumah; yakni pembimbing mengadakan dialog dengan kliennya tetapi dilaksanakan di rumah klien sekaligus untuk mengamati keadaan rumah klien dan lingkungannya. Kunjungan dan observasi kerja; yakni pembimbing atau konseling jabatan, melakukan percakapan individual sekaligus mengamati kerja klien dan lingkungannya. b. Metode Kelompok Pembimbing melakukan komunikasi langsung dengan klien dalam 
Bimbingan Konseling Islam untuk Mengatasi Depresi di Hospital Bintulu Malaysia kelompok. Hal ini dilakukan dengan teknik-teknik: diskusi kelompok; yakni pembimbing melaksanakan bimbingan dengan cara mengadakan diskusi bersama kelompok klien yang mempunyai masalah yang sama. Karyawisata; yakni bimbingan kelompok yang dilakukan secara langsung dengan mempergunakan ajang karyawisata sebagai forumnya. Sosiodrama; yakni bimbingan atau konseling yang dilakukan dengan cara bermain peran untuk memecahkan atau mencegah timbulnya masalah secara psikologis. Psikodrama; yakni bimbingan atau konseling yang dilakukan denga cara bermain peran untuk memecahkan atau mecegah timbulnya masalah secara psikologis. Group teaching; yakni pemberian bimbingan atau konseling dengan memberikan materi bimbingan atau konseling tertentu seperti ceramah kepada kelompok yang telah disiapkan.

Sebaliknya dari metode langsung adalah metode tidak langsung. Metode tidak langsung terdiri dari a. metode individual seperti: melalui surat menyurat, melalui telefon dan sebagainya b. Metode kelompok seperti: Melalui papan bimbingan, Melalui surat khabar, Melalui brosur Melalui radio Melalui televisi Layanan bimbingan konseling Islami merupakan antara layanan yang diimplementasikan di Hospital Bintulu yang terletak di Sarawak, Malaysia.

Awalnya merasa ragu terdapat divisi bimbingan konseling Islam di Hospital Bintulu. Setelah melakukan observasi ternyata terdapat layanan bimbingan konseling Islam di Hospital Bintulu. Seperti diketahui juga, satu-satunya unit yang memberikan layanan bimbingan konseling Islam di Hospital Bintulu adalah Unit Hal Ihwal Islam. Fungsi Unit Hal Ihwal Islam mengadakan acara majelis ilmu untuk petugas Hospital Bintulu, melakukan kunjungan ke ruang inap terutama ruang yang memiliki pasien kritis, menyelia atau mengurus dan membantu hal-hal yang berkaitan dengan pengurusan jenazah orang Islam. Kemudian mencari dan bekerja sama terkait masalah hukum dan fatwa yang ada kaitannya dengan masalah obat-obatan dalam Islam, menyelaras dan merancang aktivitas bersama lembaga pemerintah dari luar rumah sakit atau organisasi luar yang berdaftar, mengazankan dan iqomah kepada anak-anak yang baru lahir terutamanya kepada yang tidak berwaris, dan memberikan layanan bimbingan konseling Islam kepada pasien beragama Islam yang mempunyai masalah atau gangguan kejiwaan seperti stress, depresi dan sebagainya. Seperti yang diketahui, Unit Hal Ihwal Islam ini memberikan layanan bernuansa Islami kepada petugas hospital, pasien, ahli keluarga pasien atau siapapun warga yang membutuhkan layanan dari Unit Hal Ihwal Islam. Metode dan teknik merupakan salah satu elemen penting dalam melaksanakan layanan bimbingan konseling Islam. Tanpa metode dan teknik, layanan bimbingan konseling Islam yang diberikan ibarat "tidak bernyawa".

Metode dan teknik dalam layanan bimbingan konseling Islam dilakukan untuk mengatasi depresi pada fase dewasa awal. Tidak banyak metode dan teknik yang digunakan namun hasilnya sangat berdampak. Dalam teknik konseling terdapat beberapa tahap, yaitu, pertama, tahapan identifikasi masalah dan tahapan 
teknik konseling (Tajiri, 2018; 26). Bagaimanapun, saat ingin meminta data-data pasien secara langsung kepada Khairul Nizam Latif selalu pengurus, ternyata sangat sulit karena menyangkut etika Hospital Bintulu tentang kerahasiaan pasien. Adapun data-data pasien diperoleh melalui wawancara langsung.

Berdasarkan pemaparan di atas dapat ditarik kesimpulan bahwa metode dan teknik yang digunakan oleh pegawai Unit Hal Ihwal Islam dalam layanan bimbingan konseling Islam di Hospital Bintulu dilakukan melalui pendekatan terhadap individu pasien itu sendiri. Metode ini lebih sering digunakan karena lebih efektif dan efisien. Sedangkan teknik yang sering digunakan lebih kepada pendekatan teknik menasehati secara lemah-lembut dan mengajak pasien kembali ke jalan yang benar. Teknik ini sering digunakan karena menurut Khairul Nizam selaku pegawai Unit Hal Ihwal Islam, kebanyakan pasien yang mempunyai masalah depresi ingin mendapatkan khidmat nasihat serta bimbingan yang baik dan benar agar mereka bisa memecahkan permasalahan yang melanda jiwa mereka. Penderita juga ingin lebih tenang dalam menangani emosi atau jiwa jika gangguan itu kembali mereka alami. Metode dan teknik ini sering digunakan di Hopital Bintulu atas faktor kenyamanan pasien dalam bekerja sama dengan Unit Hal Ihwal Islam.

\section{Materi untuk Mengatasi Depresi}

Materi dan media merupakan salah satu elemen penting dalam memberikan layanan bimbingan konseling Islam agar lebih efisien dan efektif. Namun, dalam pemberian materi dan media untuk mengatasi masalah depresi mungkin terdapat kemiripan atau berlainan dari permasalahan yang lain. Materi dalam layanan bimbingan konseling Islam yang diberikan oleh Unit Hal Ihwal Islam biasanya menyesuaikan dengan permasalahan pasien. Sedangkan untuk mengatasi permasalahan depresi, terdapat beberapa materi yang biasanya digunakan oleh Pegawai Unit Hal Ihwal Islam. Antara materi yang sering digunakan oleh Pegawai Unit Hal Ihwal Islam dalam layanan bimbingan konseling Islam untuk mengatasi depresi pada fase dewasa awal seperti: a) Materi mentang ketauhidan kepada Allah. Materi ketauhidan merupakan salah satu materi terpenting dalam layanan bimbingan konseling Islam untuk mengatasi depresi. Seperti disebutkan Khairul Nizam Latif, menjadi salah satu faktor utama masalah depresi yang sering dialami pasien di kalangan usia muda. Melalui pemahaman kembali ketauhidan kepada Allah, maka secara tidak langsung pasien berupaya untuk mengenali diri sendiri dan mengetahui tujuan mereka di dunia ini bahkan lebih kuat untuk mengendalikan diri jika mengalami permasalahan yang sama. b) Materi tentang ibadah wajib dan sunat. Materi ibadah merupakan salah satu materi terpenting dalam layanan bimbingan konseling Islam untuk menangani masalah depresi, karena kebanyakan pasien tidak mengetahui cara mengerjakan ibadah terutamanya ibadah yang wajib. 
Bimbingan Konseling Islam untuk Mengatasi Depresi di Hospital Bintulu Malaysia

Salah satu materi ibadah yang diberikan Khairul Nizam Latif adalah seperti memberikan pemahaman kembali dan mengajarkan tentang shalat wajib dan sunat, memasukkan unsur zikir-zikir penenang jiwa, serta mengajarkan pembacaan Al-Qur'an kepada beberapa pasien yang amat membutuhkan. c) Materi entang akhlak. Materi tentang akhlak tidak bermaksud memberi pesan tentang akhlak, namun bermaksud agar pasien dapat merasakan aura atau citra positif tentang akhlak ketika pelaksanaan layanan bimbingan dan konseling Islam, dan secara tidak langsung para pasien juga mendapatkan materi tentang akhlak biarpun tidak mempelajarinya secara langsung.

Materi layanan bimbingan konseling Islam bersumber dari Al-Qur'an dan Al-Hadits. Tujuan materi disampaikan untuk memberikan bimbingan dan pengajaran ilmu dari ayat Al-Qur'an dan Al-Hadits. Salah satu materi yang digunakan dalam layanan tersebut adalah berhubungan dengan aqidah (tauhid), ibadah, dan akhlak (budi pekerti). (Lubis, 2007:100). Materi pokok bimbingan konseling Islam yang diberikan salah satunya adalah materi aqidah. Materi aqidah sangat penting untuk disampaikan karena aqidah merupakan masalah yang sering terjadi dalam Islam dan bagi setiap muslim sehingga bertambah dalam dirinya keimanan terhadap Allah SWT dengan segala ketentuan-Nya. Kebutuhan terhadap keimanan atau spiritual adalah harmonisasi dimensi kehidupan. Dimensi ini termasuk menemukan arti, tujuan, menderita, dan kematian; kebutuhan akan harapan dan keyakinan hidup, dan kebutuhan akan keyakinan pada diri sendiri, dan Tuhan. Ada 5 dasar kebutuhan spiritual manusia yaitu: arti dan tujuan hidup, perasaan misteri, pengabdian, rasa percaya dan harapan di waktu kesusahan (Aryanto, 2017:245)

Kuatnya kepercayaan terhadap Allah SWT akan memberi dampak terhadap kekuatan kepada manusia serta menambahkan keteguhan hati, keberanian, keaktifan, dan kedamaian batin. Keyakinan pada kebesaran ilahi juga pasti menonjolkan kesejahteraan jiwa, juga memberikan rasa aman, rasa keadilan, kepercayaan, dan harapan saat di dunia maupun akhirat (Kartono dan Andari, 1989:272).

Materi lainnya adalah tentang ibadah. Ibadah merupakan suatu bentuk pengabdian yang ditujukan kepada Allah SWT semata yang dimulai dengan niat. Segala perbuatan baik dan terpuji menurut norma ajaran Islam dapat dianggap sebagai ibadah dengan niat ikhlas karena Allah SWT. Ibadah dalam pengertian yang khusus adalah suatu pengabdian yang sudah ditetapkan oleh syari'at Islam. Misalnya seperti shalat, puasa, zakat, haji dan sebagainya. Tujuan utama pemberian materi praktek ibadah adalah untuk mengukur kemampuan dan keaktifan konseli dalam mengaplikasikan ibadah yang telah diterima sebelumnya. Materi ibadah dapat dijadikan sebagai penilaian terhadap kemampuan dan keaktifan konseli dalam menjalankan ibadah seperti shalat, do'a, dan zikir seharian. Selanjutnya akan diperbaiki jika masih ada kekeliruan oleh pembimbing.c. Materi Akhlak Materi 
akhlak merupakan pengajaran tentang bentuk batin yang kelihatan pada tingkah laku individu dimana artinya yang mendalam adalah materi yang berkaitan dengan nilai suatu perbuatan individu. Materi tersebut berkaitan dengan akhlak individu sebagai hamba Allah SWT, akhlak kepada individu, akhlak sebagai manusia kepada manusia yang lain, akhlak kepada binatang, dan akhlak kepada makhluk lain. Sedangkan tawakal adalah pemahaman manusia akan takdir terkait dengan rencana atau ketentuan Allah. Artinya mahasiswa dapat merencanakan yang dicita-citakan akan tetapi cita-citanya tidak sesuai dengan kenyataan atau keinginan sehingga menjadi sikap ikhlas atau ridho berdasarkan ketentuan Allah (Chodijah, 2016:131). Sedangkan ikhtiar adalah salah satu usaha pasien untuk memperoleh kesembuhannya.

\section{Media untuk Mengatasi Depresi}

Terkait dengan media dalam layanan bimbingan konseling Islam yang digunakan oleh Khairul Ustadz Nizam Latif, misalnya media melalui pesan atau nasihat, ayat-ayat suci Al-Qur'an, buku panduan shalat, buku zikir penenang jiwa serta beberapa kitab yang dibutuhkan untuk pemberian materi layanan bimbingan konseling Islam. Hal ini disampaikan oleh Khairul Nizam Latif saat peneliti melakukan wawancara.

Berdasarkan pemaparan di atas, dapat disimpulkan bahwa media yang digunakan oleh Khairul Nizam Latif dalam layanan bimbingan konseling Islam untuk menangani masalah depresi pasien di kalangan fase dewasa awal adalah berupa media bertatap langsung dan tidak langsung, berupa pesan atau nasihat yang berasal ayat-ayat suci Al-Qur'an, buku tentang panduan shalat, buku tentang zikir-zikir penenang jiwa, serta beberapa kitab jika dibutuhkan dalam pemberian materi layanan bimbingan konseling Islami.

\section{Hasil yang Dicapai dari Layanan Bimbingan Konseling Islam}

Melalui layanan bimbingan konseling Islam di Hospital Bintulu sangat membantu dalam menangani permasalahan yang dihadapi terutama masalah psikologis para pasien. Sepanjang proses layanan bimbingan dan konseling Islam sudah berjalan dengan baik dan lancar sehingga kondisi psikologis pasien menjadi lebih positif dari sebelum mendapatkan layanan bimbingan dan konseling Islam. Efektivitas layanan bimbingan dan konseling Islam bergantung pada kesediaan para pasien untuk menjalani layanan bimbingan dan konseling Islam, karena jika pasien menolak bantuan dalam mengatasi permasalahannya, maka kondisi kejiwaan pasien memiliki kemungkinan tidak akan berubah atau lebih parah dari sebelumnya. Oleh karena itu kesediaan pasien sangat mempengaruhi efektivitas layanan bimbingan dan konseling Islam. Hal ini juga berdasarkan hasil penelitian (Bakri \& Barmawi, 2017) jika keyakinan dari pasien bisa lebih termotivasi untuk sembuh, seperti hasil penelitiannya terhadap para pecandu narkoba. Apalagi dengan sifatnya yang pribadi, pasien pecandu rokok memiliki kesempatan 
mengungkapkan masalahnya.

Kaidah Khairul Nizam Latif dalam memberikan pencitraan diri yang positif menjadikan pasien tidak merasa canggung untuk mengikuti layanan bimbingan dan konseling Islam. Efektivitas bimbingan dan konseling Islam ditentukan oleh kedua belah pihak konselor dan konseli. Sehingga ketika dalam pelaksanaan layanan bimbingan dan konseling Islam tidak terjadi kesalahpahaman dalam memecahkan permasalahan. Hal ini dilakukan agar permasalahan dapat terarah dan bukan sebaliknya.

Adapun hasil analisa peneliti terkait implementasi layanan bimbingan konseling Islam untuk mengatasi depresi pada fase dewasa awal di Hospital Bintulu, Sarawak, Malaysia adalah sebagai berikut: a) Metode dan teknik dalam layanan bimbingan konseling Islam untuk mengatasi depresi pada fase dewasa awal di Hospital Bintulu, Sarawak, Malaysia. Layanan bimbingan konseling Islami yang diselenggarakan oleh Pegawai Unit Hal Ihwal Islam di Hospital Bintulu, Sarawak, Malaysia menggunakan metode langsung yakni pendekatan kepada metode antar individu pasien itu sendiri. Metode dan teknik realita di Hospital Bintulu ini secara tidak langsung boleh dikaitkan dengan teori menurut Aunur Rahim Faqih (2001) yang menyatakan bahwa terdapat dua metode dalam memberikan layanan bimbingan konseling Islami yaitu; metode langsung dan metode tidak langsung. Metode langsung dibagikan lagi kepada dua; metode individual dan metode kelompok.

Menurut Khairul Nizam Latif, metode langsung secara individual ini lebih efektif dan efisien untuk mengatasi depresi dibandingkan dengan metode langsung secara kelompok atau metode tidak langsung karena mayoritas pasien yang mendapatkan layanan bimbingan konseling Islam di Hospital Bintulu merasa lebih terbuka dan leluasa jika pelaksanaannya bersifat pribadi dan secara langsung bertatap muka antar dua pihak. Sedangkan teknik yang sering digunakan oleh Konselor menggunakan pendekatan teknik menasehati diri pasien secara lemahlembut serta mengajak kembali pasien ke jalan yang benar. Realita tekniknya berkaitan dengan teori Aunur Rahim Faqih (2001) yang menyatakan bahwa antara teknik yang sering digunakan dalam layanan bimbingan konseling Islam seperti; wawancara pribadi yakni melakukan dialog langsung tatap muka dengan pihak yang dibimbing, kunjungan ke rumah, atau kunjungan dan observasi kerja. Maka antara teknik yang sesuai dan sering digunakan oleh oleh Konselor selaku Pegawai Unit Hal Ihwal Islam jika teori dikaitkan dengan realita lapangan di Hospital Bintulu adalah seperti wawancara pribadi yaitu melakukan dialog langsung bertatap muka dengan pasien yang bersedia untuk dibimbing.

Wawancara pribadi direalisasikan melalui dialog pribadi antar dua pihak tentang permasalahan psikologi pasien, jika pasien membutuhkan saran dari pihak pembimbing, maka pihak pembimbing akan memberikan nasihat kepada para pasien. Teknik ini sering digunakan oleh Konselor yang juga Pegawai Unit Hal 
Ihwal Islam karena kebanyakan dari pasien yang menerima layanan bimbingan konseling Islam di Hospital Bintulu sudah pasti menginginkan saran Konselor dalam memecahkan permasalahan pada diri mereka.

Berdasarkan analisis di atas peneliti menyimpulkan bahwa teori metode dan teknik dengan realita di lapangan relevansinya kuat dan berkesesuaian antara teori dan prakti di lapangan yang dilakukan oleh Konselor Hospital Bintulu, Sarawak, Malaysia. Lalu, materi dan media yang digunakan dalam layanan bimbingan konseling Islam untuk mengatasi depresi pada fase dewasa awal di Hospital Bintulu, Sarawak, Malaysia sejalan dengan materi dan media dalam layanan bimbingan konseling Islam menurut para ahli yang sudah dipaparkan melalui kajian teori. Kedua-duanya memiliki persamaan dari segi pemberian materi dan media dalam layanan bimbingan konseling Islam kepada para pasien. Teori tentang materi yang dikemukakan oleh para ahli seperti Lubis (2009) erat kaitannya dengan aqidah yakni ketauhidan, ibadah, dan akhlak yakni budi pekerti. Hal serupa dilakukan oleh Konselor Khairul Nizam Latif yang melibatkan materi tentang ketauhidan kepada Allah, materi tentang ibadah wajib dan sunat, serta materi tentang mempraktikkan akhlak secara tidak langsung kepada para pasien untuk mengatasi masalah depresi. Materi tentang ketauhidan di sini seperti; memberikan pengenalan atau berkongsi kepada pasien tentang kewujudan Allah dengan lebih meluas, apa tujuan kita diciptakan di dunia ini, kenapa setiap manusia itu diuji dengan ujian yang berbeda dan sebagainya. Sedangkan, untuk materi tentang ibadah wajib dan sunat adalah seperti; memberi pemahaman kembali tentang shalat terutama bagi pasien yang tidak mengetahui maupun dari segi bacaan di dalam shalat, berkongsi tentang zikir-zikir untuk menenangkan jiwa kepada para pasien, serta mengajarkan pembacaan Al-Qur'an bagi para pasien yang berkeinginan.

Materi tentang akhlak menekankan pada pemaparan akhlak dari pihak konselor kepada kepada konseli. Seperti teori tentang media yang dikemukakan oleh Enjang (2009) yaitu; media sekarang banyak sekali yang digunakan untuk efektivitas dalam proses konseling. Salah satu medianya seperti; telepon, media cetak, media e-mail dan sebagainya. Sedangkan media yang digunakan oleh Pegawai Unit Hal Islam di Hospital melalui bantuan media cetak seperti; AlQur'an, buku panduan shalat, buku zikir-zikir penenang jiwa, serta kitab-kitab yang berkaitan sebagai panduan memberikan materi layanan bimbingan dan konseling Islami.

Merujuk pada hasil wawancara dengan Konselor Khairul Nizam Latif serta pemaparan di atas, terdapat persamaan antara materi dan media yang diberikan dalam layanan bimbingan konseling Islami di Hospital Bintulu dengan teori menurut beberapa ahli yang sudah dipaparkan di kajian teori sebelumnya.

Terkait dengan dampak yang ditimbulkan dari layanan bimbingan konseling Islam dalam mengatasi depresi pada fase dewasa awal di Hospital Bintulu, 
Bimbingan Konseling Islam untuk Mengatasi Depresi di Hospital Bintulu Malaysia Sarawak, Malaysia terdapat perubahan dampak yang positif pada diri pasien setelah menerima layanan bimbingan konseling Islam menurut hasil wawancara kepada Pegawai Unit Hal Ihwal Islam di Hospital Bintulu. Menurut peneliti bahwa keefektifitasian dalam layanan bimbingan konseling Islami amat bergantung kepada kesiapan para pasien untuk lebih terbuka dalam perkongsian permasalahan kepada Pegawai Unit Hal Ihwal Islam agar masalah tersebut lebih terarah dan mudah untuk dipecahkan permasalahannya.

\section{PENUTUP}

Implementasi layanan bimbingan konseling Islam untuk mengatasi depresi pada fase dewasa awal di Hospital Bintulu, Sarawak, Malaysia menggunakan metode dan teknik langsung secara individual dan teknik wawancara pribadi antar individu seperti sesi dialog pribadi antar dua pihak tentang permasalahan psikologi pasien. Metode dan teknik ini digunakan karena mayoritas pasien yang menerima layanan bimbingan konseling Islam akan merasa lebih terbuka dan leluasa dengan pihak konseli jika proses pelayanannya lebih kepada wawancara pribadi antar dua pihak. Menurut Pegawai Unit Hal Ihwal Islam lagi bahwa kebanyakan dari para pasien yang menerima layanan bimbingan konseling Islami di Hospital Bintulu sudah pasti ingin mendapatkan saranan serta nasihat daripada pihak beliau dalam memecahkan permasalahan pada diri mereka.

Materi dan media yang sering digunakan yaitu; materi tentang aqidah misalnya; pemahaman kembali ketauhidan kepada Allah, serta materi tentang ibadah misalnya, memberikan pemahaman dan mengajarkan kembali tentang shalat wajib dan sunat, berkongsi tentang zikir-zikir penenang jiwa serta mengajarkan pembacaan Al-Qur'an kepada beberapa pasien yang amat membutuhkannya. Sedangkan untuk media dalam pelaksanaan materi layanan bimbingan konseling Islam adalah seperti media dalam berupa pesan atau nasehat, ayat-ayat suci Al-Qur'an, buku panduan shalat, buku zikir-zikir penenang jiwa serta beberapa kitab sebagai panduan dalam memberikan materi layanan bimbingan konseling Islami untuk mengatasi depresi.

Implementasi layanan bimbingan konseling Islam membantu para pasien menjadi lebih positif serta aktivitas yang semakin normal. Keberhasilan atau efektivitas ini bergantung kepada kesiapan para pasien untuk bersikap terbuka untuk menyelesaikan permasalahannya. Komunikasi yang baik antara konselor dengan para pasien selaku konseli turut mendukung sebagai faktor utama efektivitas proses layanan bimbingan konseling Islam. Kesadaran diri pasien turut dibutuhkan dalam menjalankan kegiatan yang dituntut dalam bimbingan konseling Islam.

\section{DAFTAR PUSTAKA}

Adz-Dzaky, H.B. (2006) Konseling \& Psikoterapi Islam, Yogyakarta : Fajar Pustaka 
Ahmad Samerin bin Abu Bakar

Baru

Amin, S. M. (2013). Bimbingan dan Konseling Islam, Jakarta: Amzah

Aryanto, I. (2017). Pelaksanaan Bimbingan Perawatan Rohani Islam (Warois) Untuk Memenuhi Kebutuhan Spiritual Pasien. Irsyad Jurnal Bimbingan Penyuluh, Konseling dan Psikoteri Islam. 5 (3) 241-260.

Bakri, M. \& Barmawi, B. (2017) Efektifitas Rehabilitasi Pecandu Narkotika Melalui Terapi Islami Di Badan Narkotika Nasional (BNN) Banda Aceh, dalam Jurnal PsikoIslamedia, 2 (1): 86-95.

Chodijah, S. (2016). Model Bimbingan dan Konseling Komprehensif dalam Meningkatkan Akhlak Mahasiswa. Ilmu Dakwah: Academic Journal for Homiletic Stadies. 10 (1) 129-146.

Enjang, E. (2009) Komunikasi Konseling. Bandung: Nuansa.

Faqih, A. R.(2001). Bimbingan dan Konseling dalam Islam, Jakarta: UII press

Hallen, A. (2002). Bimbingan dan Konseling, Jakarta: Ciputat Pers

Hurlock, E.B. (2003). Psikologi Perkembangan: Suatu pendekatan sepanjang rentang kehidupan, Jakarta: Erlangga

Kartono, K. \& Andari, Jenny (1989). Hygiene Mental dan Kesehatan Mental dalam Islam, Bandung: Mandar Maju.

Kenwa, P. (2015) Pengaruh Pemberian Konseling terhadap Depresi Post Partum di Puskesmas II Dan IV Denpasar Selatan, dalam Coping Ners Journal, 3 (2): 1-6.

Lubis, N. L. (2011). Memahami Dasar-Dasar Konseling dalam Teori dan Praktek, Jakarta: Kencana.

Maloeng, L.J, (2007). Metodologi Penelitian Kualitatif. Bandung; Cv; Rosdakarya

Mubarok, A. (2002). Al-Irsyad an Nafsy, Konseling Agama Teori dan Kasu Yogyakarta: Fajar Pustaka Baru.

Novia, I. \& Thohir, M. (2013) Bimbingan dan Konseling Islam dengan Terapi Silaturahmi pada Seorang Remaja yang Mengalami Depresi, dalam Jurnal Bimbingan dan Konseling Islam, 3 (1): 76-95.

Nuhayati, U. (2018). Pelaksanaan bimbingan agama Islam dalam mengatasi depresi pada lansia di rumah pelayanan sosial lanjut usia Wening Wardoyo Ungaran (Doctoral dissertation, UIN Walisongo).

Santrock. (2002). Life-Span Development (Perkembangan Masa Hidup). Jilid 2. Jakarta: Erlangga.

Suryani, S., Widianti, E., Hernawati, T., dan Sriati, Aat. (2016) Psikoedukasi Menurunkan Tingkat Depresi, Stres Dan Kecemasan Pada Pasien Tuberkulosis Paru, dalam Jurnal Ners, 11 (1): 128-133.

Tajiri, H. (218). Pendekatan Konseling Spiritual dalam Penyembuhan Pasien Narkoba di Inabah VII Tasikmalaya. Anida (Aktualisasi Nuansa Ilmu Yosep Dakwah). 18 (1) 21-40.

Yosep, H. Iyus dan Sutini, T. (2016). Buku Ajar Keperawatan Jiwa, Bandung: PT 
Refika Aditama

Bimbingan Konseling Islam untuk Mengatasi Depresi di Hospital Bintulu Malaysia

Mutia, E. Subandi, dan Mulyati, R. (2011) Terapi Kognitif Perilaku Bersyukur untuk. Menurunkan Depresi pada Remaja, dalam Jurnal Intervensi Psikologi, 2 (1), 53-68.

Razak, A. (2013) Terapi Spiritual Islami Suatumodel Penanggulangan Gangguan Depresi, dalam Tabligh, Jurnal Dakwah, 14 (1): 141-151.

Rofiq, A.A. (2012) Terapi Islam dengan Strategi Thought Stopping dalam Mengatasi Hypochondriasis, dalam Jurnal Bimbingan dan Konseling Islam, 2 (1): 65-74.

Sutoyo, A. (2007). Bimbingan dan Konseling Islam (Teori dan Praktik). Semarang: CV Cipta Prima Nusantara 